\title{
Youth and Moral Values in a Changing Society
}

\author{
${ }^{1}$ Dr. Ime N. George $\&{ }^{2}$ Unwanaobong D. Uyanga \\ ${ }^{1,2}$ Faculty of Education, University of Uyo PO box 1017, UyoAkwalbom State, Nigeria
}

\begin{abstract}
It has been stated and rightly so too that the future of any nation rests on the shoulders of youths of today as they will eventually become the leaders of tomorrow. Therefore, anything targeted at this group of persons must be worthwhile and directed at helping them fulfill their purpose as would-be leaders. Leadership is an art as well as an activity through which the affairs of men in the society are directed in line with the attainment of goals. As youths get prepared for leadership roles; it is pertinent to acquire moral standards and values that will mold them into personalities ready to lead for the progress of the society. This paper is a discourse on how our changing society impacts on youth and moral values.
\end{abstract}

Keywords: Youth, moral value, Morality, Societal change, Value system

\section{Introduction}

Leadership comes to the fore in societies where men search for comfort, justice and harmony. As men willingly enter into communal living, giving up solitary existence, it becomes important to note that man's life has meaning only in relationship and this meaning can only be attained through the activity of people who share the same vision (Enemuo\&Nzulumike; 2009). Youths need to be morally disposed rightly in order to develop themselves first and then society. Without this, leadership becomes futile as it is intricately linked with goal attainment and these goals can be achieved by the whole of society and not a part. Schweitier quoted in Omoregbe (1979) and cited in Anadi (2008) avers that "the prosperity of a society depends on the moral dispositions of its members". Prosperity connotes success, affluence and achievement and for any society to enjoy these qualities, her members, most importantly, her youths must imbibe right moral values that will dispose them to become positively oriented leaders of tomorrow.

This article will delve into discussing who a youth is, what moral values are, state some conflicting values of the past and present and moral values for youths in a changing society. Recommendations will be made and conclusions will be drawn from the discussions.

\subsection{The Concept of Youth}

Youths are the engine room of societies. They are the drivers of any developmental trend and activity in society and major determinants of the extent of growth and development in any given society. Youths are usually very energetic and are always willing to go the extra mile if need be to achieve what they believe in and hold on to. The Oxford Advanced Learner's Dictionary (2010) defines youth as "the time of life when a person is young especially the time before a child becomes an adult". Olujide (2008) quoting the National Youth Development Plan of 2001 defines youth as "young persons of ages 18-35 years who are citizens of the Federal Republic of Nigeria". Other groups' state different age brackets to embrace a person identified as a youth. The United Nations General Assembly identifies a youth within the age bracket of 18-34 years; the Commonwealth Youth Programme pegs the age bracket at 15-29 years while the Danish Youth Council places youths in the age bracket of 15-34 years (http://en.wikipedia.org/wiki/youth).

Youths are usually referred to as young persons but judging from the above age brackets, specific ages cannot be given for a person to be identified as a youth. This can be better explained using the National Youth Service Corps (N.Y.S.C) Scheme as an example. This scheme establishes the statement that to qualify for the scheme, the participating youth must not be more than thirty years of age. The contradicting age brackets of youths as cited above cannot therefore make age alone a reliable factor in determining who a youth is. That is why in line with Mabogunje and Obasanjo (1990) in Oyebamiji (2008), youths will be identified as young persons who manifest the following behavioural characteristics:

- A strong desire to move up the ladder;

- A tendency to be idealistic as a result of the values passed into them at earlier ages by role models in the society;

- An eagerness to live to this role models and

- Frequent frustrations and anxiety as this idealism confronts the cold realism of daily existence.

In addition, youths are very energetic, excessively ambitious young persons who desire to change things or situations overnight; as quickly as possible and in the shortest possible time frame. Having these characteristics, 
young persons can be helped by present day leaders to reduce to the barest minimum their frustrations and anxiety in society by putting relevant measures in place to motivate them and also positively harness their strength and vigor for positive change and development in society. One of the behavioural characteristics stated above is that of a tendency to be idealistic. Youths are actually very idealistic as they are taught right from childhood to value "unchanging" ideals such as justice, fairness and equality; brought up in a culture that promotes ideals and "idea of permanence". These ideals are taught them in form of moral values which they learn as they grow up. What then are moral values?

\subsection{The Concept of Moral Values}

We cannot begin to analyze what moral values are without first having an understanding of what morality and moral education are. Morality is derived from the Latin word mores which means "manners" or "morals". In the words of Aminigo and Nwaokugha (2006); morality is "an accepted code of human conduct in a society". Morality entails "having laws that will regulate dealings of men who can choose to abide by these laws because they know it is good sense to do so" (Uyanga and Amingo; 2010). Being moral or being morally conscious means adopting standards or principles to guide ones' actions and conduct in society. Moral education is a programme of study which teaches the pupil about behaving in accordance with what is good while rejecting the bad. It is a holistic approach to stimulate character building and moral development (Okoh; 2003). Moral education should lead youths to develop from a stage of anomie; often characterized by pre-morality to a stage where an individual is not forced to be moral and is personally convinced on standards that ought to guide his/her conduct in society.

Moral values are taught in moral education as certain acceptable, valuable and cherished qualities that are worthwhile in developing a sound character. Osaat (2004) in Ekpiwre (2008) defines values as "things considered worthwhile, desirable, right and good and thus craved for and applied on a daily basis to enhance existence by the people". Values determine people's identity and cultural continuity. Moral values are essential values that determine individuals' perception of morality and moral consciousness in society. Moral values include truthfulness, patience, obedience, honesty, integrity, hard work, responsibility, respect, tolerance, loyalty, public spiritedness, freedom, respect for human life and dignity of persons. Others include justice, fairness and equality.

Moral values are taught to be imbibed by members of the society to enhance character development and promote good moral upbringing and moral health in individuals. As Amingo (2003) argues "moral health is manifested in individuals when a person becomes capable of understanding the principles of moral conduct and is committed to behaving morally in his dealings with others". Principles of moral conduct can only be effectively understood and practiced when moral values are strongly adhered to by individuals in a given society.

\section{Conflicting Values of the Past and Present}

Society is dynamic not static and as societies change from simple traditional societies to complex modern societies; people, values, trends and activities also change. For instance, traditional African societies where relatively simple with no literary heritage (Ibia; 2006) as oral transmission was what was in vogue as opposed to the modern African societies which have been greatly influenced by the Western world and is more advanced with a lot of literary collections on an array of subjects. Just as societies have developed, values have also continued to change to suit the character of a changing world which has brought in an increased wave of moral decadence and moral laxity in present day societies. Some cherished and upheld moral values of the past include:

\subsection{Truthfulness}

This quality can be defined as being honest. Honesty implies being frank, direct, open or even straight. It entails standing up for what you believe in no matter whose pride gets in the way. It means not contradicting oneself in thoughts, words and actions. Isichei and Bolaji (2010) define honesty as "the awareness of what is right and appropriate in one's role, one's behavior and one's relationship". Honesty is the foundation of integrity; having moral standards. Traditional societies were founded on this value and truthfulness was a quality pursued by all especially by leaders who were looked up to for direction by followers. Leaders valued truthfulness because they believed in protecting their names and reputation. They cherished the saying of Proverbs 22:1- "a good name is rather to be chosen than great riches and loving favor rather than silver or gold". They lived in line with this saying even when they had not read the bible.

\section{$2.2 \quad$ Respect}

Respect is an acknowledgement of the inherent worth and innate rights of the individual and collectivity (Isichei and Bolaji; 2010). The value of respect was cherished in the past, especially respect for 
elders. This is because it was assumed that elders were more knowledgeable and wiser than young persons. Respect was also given to elders as they comported themselves in manners worthy of emulation. Respect comes with honour and dignity as the individual or group of individuals are regarded as important personalities in their own rights.

\subsection{Tolerance and Cooperation}

The Bible asks a salient question in Amos 3: 3; Can two people work together if they do not agree? The most logical answer is No. This is because one person will always drawback the other. For persons to work together to accomplish set objectives, they must learn to appreciate their differences, accommodate their weaknesses and pull together their strengths. Tolerance means being receptive to the beauty of differences while cooperation is simply identified as team work. Tolerance involves mutual understanding resulting from mutual respect while cooperation involves mutually beneficial relations. Traditional societies were tolerant and extremely cooperative, they appreciated diversity in nature and realized that though they were different, they had to work together to promote human life and existence.

\subsection{Hard work and Functionalism}

Traditional societies cherished the virtues of hard work and functionalism. Everything these societies did was geared towards inculcating these values in the younger generations. Traditional African education was very functional in its approach as it comprised basic education for living in conformity with the traditions of the community; education for occupation and economic self-reliance for equipping members with appropriate skills for survival and education for special occupation with regards to particular families -family crafts, medicine etc (Kosemani\&Okorosaye-Orubite 1995). Traditional societies did not support laziness and as such did not encourage it. Individuals had to learn to value hard work as a channel for an improved life. Members were encouraged to be functional by contributing wholly to the proliferation of their societies. Societies encouraged members of the society who were committed to these values by rewarding them in various ways especially with leadership positions.

\subsection{Respect for human life and Dignity of persons}

Human life has always been sacred or sacrosanct. Life has always been important and the dignity of persons has been pursued because the origin of life has been linked with "gods" or "deities". Human belief in the ultimate power of "immortal gods" has caused men to have great respect for human life and regard persons with dignity. Traditional societies promoted the security of life because of their beliefs in its sacredness. Before life was taken, it had to be a necessary sacrifice after a series of interventions of the people for adequate cleansing.

Traditional societies as already stated were very simple societies. They believed in character development and functionalism of members and they pursued this cause with utmost sincerity. Most of their determination to pursue just causes arose from their religious beliefs in the supremacy of their "gods" and the punishment(s) that could arise as a result of their disobedience of these "gods". In the words of Kosemani and Okorosaye- Orubite (1995) again, "the yard stick for measuring an educated man is his morals, manners, obedience to authority and respect for the customs, conventions, superstitions and laws of the land".

\subsection{Values of the Present}

With civilization came a lot of changes both positively and negatively. One negative change that came with 'the dawn of the new era' was moral decadence and laxity. Society has witnessed a fall in moral standards and an increased interest in pleasure and enjoyment as opposed to more serious things. Moral decadence has resulted in indiscipline at all levels in the society and its resultant effects are seen in our lackadaisical attitude to work; our readiness to cheat and embezzle, lack of dignity and respect for human life and the monster of corruption. Values that are predominantly held and pursued today include dishonesty, disrespect, intolerance and lack of cooperation, profit oriented relationships, profane of life and abuse of human dignity, loss of pride in hard work and an increased interest in the pursuit of injustice and other crimes all in a bid to acquire wealth by adopting the philosophy that "the end justifies the means". Modern societies are experiencing the wave of corruption driven by the "get rich quick syndrome". Public goods and resources are audaciously stolen by individuals who are in leadership positions in a bid to acquire wealth for themselves and secure the future of their families caring less about the pain and burdens to be borne by other members of the society as a consequence of their actions. Today, people take pride in telling lies, engaging in ungodly practices and embellishment of various criminal acts. Integrity is lacking in the interactions of men with one another and flagrant abuse of the laws and of human rights is the order of the day. 


\section{Moral Values for Youth in a changing Society}

"Train up a child in the way he should go: and when he is old, he shall not depart from it" (Prov. 22: 6). This saying is as important for the child as it is for the youths. In a world were development continues to take place and societies rapidly move with latest developmental trends; it is very important for youths to hold on to moral values taught them in their childhood. In as much as societies continue to change, there are certain principles that genuinely focused societies want to strictly adhere to. Youths are being faced with peculiar problems in their societies that tend to challenge their moral stance, they are surrounded with people who have thrown morality aside and are 'making it'. Society tends to favor those who can do almost anything to attain power and money and even celebrates corruption in several ways. Notwithstanding this, youths have the power that lies within them to bring about the societies they want. In as much as they continue to observe such sad practices, they can choose to make a positive impact in society by the way they live. Still, the world celebrates men and women of great values who held on and continue to hold on to values that are undeniable and true. The Late South African President, Nelson Mandela, is celebrated the world over as a truly remarkable man who changed the face of South Africans and made black South Africans proud young men and women whose spirits were dampened by the apartheid era. This he did as a young man. Mandela stood for truth, justice and freedom and is today hailed as a hero, an icon and a man of the people. The young Pakistani youth, MalalaYousafzai stands out as a youth with values. She continues to advocate for good even in the face of persistent danger. Youths especially in our dear country Nigeria, do not need to follow the path of destruction by not being morally conscious but can make a difference in their society by doing what is right. Life always presents choices; man is always a product of his choices. What you choose can make or mar you. Being a total man with knowledge, competence (skills) and right attitudes can leave lasting legacies for the future of any society. Moral values of the past can still be practiced by youths in present day societies and with this they (youths) can determine the type of change that occurs in society and not just be swept off their feet and be victims of the changes that are bound to occur in a changing world. In the book titled: Maximizing your youthful season; Onuoha quoting Bernard Shaw writes "the reasonable man adapts himself to the world; the unreasonable man persist in trying to adapt the world to himself; therefore, all progress depends on the unreasonable man". Youths of today can make a difference in their societies by standing out of the crowd and upholding moral values in a morally bankrupt society.

\section{Recommendations}

1. The family which is the base structure of every society must begin to right their wrongs with regards to restructuring their value systems because most youths learn from the elders in their families and if truly there has to be a positive change in society, the family must play its role as the major primary agent of socialization in the society.

2. Government and other authorities especially in leadership positions must see themselves as role models for young persons and begin to be responsible adults. They have to realize that the future of tomorrow depends on the foundations laid today and youths cannot become trusted leaders if they cannot follow in trust.

3. Youths must encourage themselves by interacting with one another and creating social networks that can easily strengthen them when faced with discouraging attitudes about moral issues. This can bring about the institution of a strong and viable moral base founded on principles that work.

4. The national goals for the inculcation of national consciousness and national unity and the inculcation of the right type of values and attitudes for the survival of the individual and the Nigerian nation can become a reality if the Nigerian nation adopts moral values that will be recognized as its core identity and encourage its spread among its youths by proving that this identity penetrates all facets of life and is worthwhile.

\section{Conclusion}

Youths are major determinants of the level of development in any society. Without youths, there can be no sustenance of society as no society can be self-sustaining without its human components of which the major workforce is the youths. Realizing this, young people ought to know their importance and worth in society and begin to value themselves as purveyors of the fortune and progress of any society. Youths must be committed to imbibing moral values and upholding them through life as these values will shape the ways they think, speak and even act. Moral standards can rise in contemporary societies if the zeal of youths brings about the restoration of moral values. To uphold moral values, youths must be disciplined and resist immoral behaviour that will eventually culminate in loss of moral compass. Youths can be the agents of change in their societies by accepting to live by moral codes and become "lights in perceived darkness" to show the way forward for nations to become truly prosperous, developed and functional. 


\section{References}

[1]. Aminigo, I. M. (2003). Model Essays in Moral Education. Buguma: Hanging Gardens Publishers

[2]. Aminigo, I. M. \& Nwaokugha, D. O. (2006). An Advanced Introduction to Philosophy of Education. Choba: Zelta Research Consult

[3]. Anadi, C. C. (2008). Moral Values for the production of Disciplined Manpower in Primary Schools. Nigerian Journal of Sociology of Education, 2 (2): 35-45

[4]. Ekpiwre, C. A. (2008). Socialization and Value Re-Orientation in the Family: Implications for Effective Education Reforms in Nigeria. Nigerian Journal of Sociology of Education, 2 (2): 174-180

[5]. Enemuo, P. C. \& Nzulumike, C. (2009). Education, Leadership and National Development.Nigerian Journal of Educational Philosophy, 21 (1): 69-80

[6]. Ibia, E. I. (2006). Sociological Foundations of Nigerian Education (Rev. ed). Uyo: On'pex Publisher

[7]. Isichei, F. M \& Bolaji, S. D. (2010). Relevance of Philosophy of Education to National Value Re- Orientation. Nigerian Journal of Educational Philosophy, 1(1): 22-30

[8]. Kosemani, J. M. \& Okorosaye- Orubite, A. K. (1995). History of Nigerian Education: A Contemporary Analysis. Port Harcourt: Abe Publishers

[9]. Okoh, J. D. (2003). Philosophy of Nigerian Education (The Basics). Owerri: Corporate Impressions

[10]. Olujide, M. G. (2008). Attitude of Youth towards Rural Development Programmes in Lagos State, Nigeria. Journal of Social Sciences, 17 (2)

[11]. Onuoha, D. C. (2005). Maximizing Your Youthful Season. Umuahia: Empowerment Publications

[12]. Oxford Advanced Learners Dictionary (2010). International Student's edition (8th ed). Oxford University Press

[13]. Oyebamiji, M. A. (2008). Constraints to Participation of Nigerian Youths in Community Development: Implications for National Development. Journal of Adult and Community Education Research, 1 (1)

[14]. Uyanga, U. D. \& Aminigo, I. M. (2010). The Morally Autonomous Individual and National Development Imperatives in the Nigerian Nation. Trends in Educational Studies, 5 (1 \& 2): 1-8 